\title{
GAMBARAN KEKUATAN OTOT PADA LANSIA DI BPLU SENJA CERAH PANIKI BAWAH
}

\author{
${ }^{1}$ Prisilia M. Pinontoan \\ ${ }^{2}$ Sylvia R. Marunduh \\ ${ }^{2}$ Herlina I. S. Wungouw
}
${ }^{1}$ Kandidat Skripsi Fakultas Kedokteran Universitas Sam Ratulangi Manado
${ }^{2}$ Bagian Fisiologi Fakultas Kedokteran Universitas Sam Ratulangi Manado Email : ppinontoan11_015@yahoo.com

\begin{abstract}
The aim of this study was to find out the profile of muscle strength on elderly at BPLU Senja Cerah Paniki Bawah. This was a descriptive study with cross sectional design. There were 26 respondents who met the inclusion criteria, consisted of 10 elderly men and 16 elderly women. Respondents were selected by using purposive sampling method. The measurements of the muscle strength were done by using $1 \mathrm{RM}$ method while doing elbow flexion, elbow extension, shoulder flexion, shoulder extension, shoulder abduction, knee flexion, knee extension and dorsoflexion. Data were analyzed manually and computerized then presented in tabular form. The result shows that the average muscle strength in elderly men were greater than women and the average muscle strength of respondents that were included in the age group 60-79 years old were greater than those in 80-99 years.
\end{abstract}

Keywords: muscle strength, elderly.1 RM

\begin{abstract}
Abstrak: Tujuan dari penelitian ini yaitu untuk mengetahui gambaran kekuatan otot pada Lansia di BPLU Senja Cerah Paniki Bawah. Penelitian ini merupakan peneliltian deskriptif dengan rancangan potong lintang. Responden yang memenuhi kriteria inklusi terdiri dari 26 orang yang terdiri dari 10 orang laki-laki dan 16 orang perempuan. Sampel dipilih menggunakan cara purposive sampling. Kekuatan otot pada lansia diukur dengan menggunakan metode $1 \mathrm{RM}$ yang diukur pada gerakan fleksi siku, ekstensi siku, fleksi bahu, ekstensi bahu, abduksi bahu, fleksi lutut, ekstensi lutut serta dorsofleksi. Data yang sudah didapatkan kemudian dikumpul dan diolah secara manual dan komputerisasi serta disajikan dalam bentuk tabel. Hasil penelitian menunjukkan rerata kekuatan otot responden laki-laki lebih besar dibanding perempuan dan rerata kekuatan responden yang termasuk dalam kelompok umur 60-79 tahun lebih besar dibanding kelompok umur 80-99 tahun.
\end{abstract}

Kata kunci: kekuatan otot, lansia, 1 RM.

Jumlah penduduk lanjut usia terus meningkat dari tahun ke tahun seiring dengan meningkatnya usia harapan hidup. ${ }^{1}$ Dalam Undang-undang Nomor 13 tahun 1998 tentang Kesejahteraan Lanjut Usia, yang dimaksud dengan lanjut usia (lansia) adalah penduduk yang telah mencapai usia 60 tahun ke atas. Mulai tahun 2010 diperkirakan akan terjadi ledakan jumlah penduduk lanjut usia. Hasil prediksi menunjukkan bahwa persentase penduduk lanjut usia akan mencapai 11,34 persen dari total penduduk pada tahun 2020 . $^{2}$

Setiap orang mengalami proses penuaan. Proses penuaan mengakibatkan terjadinya perubahan anatomik dan fungsional dari organ-organ tubuh. Diantaranya perubahan pada sistem panca- 
indra, gastro-intestinal, kardiovaskuler, respirasi, endokrinologi, hematologik, persendian, otot, tulang, dan lain-lain. ${ }^{3}$

Penurunan kekuatan otot merupakan salah satu perubahan yang nyata dari proses penuaan. Menurunnya kekuatan otot disebabkan oleh banyak faktor. Faktor penyebab yang utama yaitu penurunan massa otot. ${ }^{4}$ Penurunan kekuatan otot ini dimulai pada umur 40 tahun dan prosesnya akan semakin cepat pada usia setelah usia 75 tahun. Para peneliti dari Columbia University Medical Center menemukan bahwa menurunnya kekuatan otot pada penuaan terjadi akibat kebocoran kalsium dari kelompok protein dalam sel otot yang disebut ryanodine yang kemudian memicu terjadinya rangkaian kejadian yang membatasi kontraksi serabut otot. Dengan berkurangnya kalsium yang tersedia, kontraksi otot melemah. ${ }^{5}$

Penurunan kekuatan otot yang terjadi pada lansia dapat mengakibatkan kesulitan dalam melakukan aktivitas sehari-hari. Kesulitan dalam beraktivitas sehari-hari mengakibatkan lansia membutuhkan bantuan dari anggota keluarga. Selain itu, terbatasnya aktivitas fisik dari lansia dapat memicu terjadinya berbagai penyakit. ${ }^{3}$ Untuk mencegah terjadinya penurunan kekuatan otot pada lansia terdapat banyak macam latihan fisik yang dapat dilakukan. Salah satu latihan yang dapat dilakukan yaitu Strength Training. Strength training yang progresif dapat meningkatkan kekuatan otot dan mempertahankan fungsi motorik. $^{6}$

Berdasarkan uraian diatas maka peneliti tertarik untuk melakukan penelitian dengan judul " Gambaran Kekuatan Otot pada Lansia di BPLU Senja Cerah Paniki Bawah”.

\section{METODE PENELITIAN}

Penelitian ini merupakan peneliltian deskriptif dengan rancangan potong lintang. Dilakukan pada bulan oktober desember 2014 di Balai Penyantunan Lanjut Usia (BPLU) Senja Cerah Paniki Bawah. Populasi pada penelitian ini adalah seluruh lansia yang tinggal di BPLU Senja
Cerah Paniki Bawah. Didapatkan sampel sebanyak 26 orang yang terdiri dari 10 orang laki-laki dan 16 orang perempuan. Sampel dipilih menggunakan cara purposive sampling. Kekuatan otot pada lansia diukur dengan menggunakan metode $1 \mathrm{RM}$ yang diukur pada gerakan fleksi siku, ekstensi siku, fleksi bahu, ekstensi bahu, abduksi bahu, fleksi lutut, ekstensi lutut serta dorsofleksi. Data yang sudah didapatkan kemudian dikumpul dan diolah secara manual dan komputerisasi serta disajikan dalam bentuk tabel.

\section{HASIL PENELITIAN}

Selama bulan oktober - desember 2014 telah dilakukan penelitian pada lansia berumur 50 tahun ke atas yang tinggal di Balai Penyantunan Lanjut Usia Senja Cerah Paniki Bawah. Pada penelitian diperoleh 30 orang yang memenuhi kriteria inklusi. Saat dilakukan pengukuran empat diantara 30 orang yang memenuhi kriteria inklusi mengalami drop out sehingga jumlah responden yang dianalisis sebanyak 26 orang.

\section{Karakteristik Responden Jenis Kelamin}

Tabel 1 menggambarkan jumlah responden penelitian menurut jenis kelamin. Sebagian besar responden terdiri dari perempuan dengan jumlah 16 orang (61,5\%) dan laki-laki 10 orang (38,5\%).

Tabel 1. Distribusi Responden berdasarkan Jenis Kelamin

\begin{tabular}{ccc}
\hline Jenis Kelamin & $\mathrm{N}$ & $\mathbf{\%}$ \\
\hline Laki-Laki & 10 & 38.5 \\
Perempuan & 16 & 61.5 \\
Total & 26 & 100.0 \\
\hline
\end{tabular}

\section{Umur}

Tabel 2 menggambarkan distribusi umur dari responden. Responden dengan umur kisaran 60-69 tahun berjumlah 4 orang $(15,4 \%)$, kisaran 70-79 tahun berjumlah 12 orang (46,2\%), 80-89 tahun berjumlah 9 orang (34,6\%), sedangkan 
responden yang berumur kisaran 90-99 tahun hanya 1 orang $(3,8 \%)$.

Tabel 2. Distribusi Responden berdasarkan Kelompok Umur

\begin{tabular}{ccc}
\hline Kelompok Umur & $\mathrm{N}$ & $\mathbf{\%}$ \\
\hline $60-69$ & 4 & 15,4 \\
$70-79$ & 12 & 46,2 \\
$80-89$ & 9 & 34.6 \\
$>90$ & 1 & 3.8 \\
Total & 26 & 100.0 \\
\hline
\end{tabular}

\section{Gambaran Kekuatan Otot berdasarkan Jenis Kelamin}

Tabel 3 menggambarkan rerata kekuatan otot berdasarkan jenis kelamin. Pada gerakan fleksi siku, ekstensi siku, fleksi bahu, ekstensi bahu, abduksi bahu, fleksi lutut dan ekstensi lutut rerata kekuatan otot pada laki-laki lebih besar daripada perempuan. Pada gerakan dorsofleksi kiri dan kanan, rerata kekuatan otot pada perempuan (1,40 kg dan 1,29 kg) lebih besar daripada laki-laki (1,35 kg dan 1,2 $\mathrm{kg})$.

Tabel 3. Rerata Kekuatan Otot berdasarkan Jenis Kelamin

\begin{tabular}{|c|c|c|}
\hline \multirow[t]{2}{*}{ Gerakan } & \multicolumn{2}{|c|}{$\begin{array}{c}\text { Rerata Kekuatan Otot } \\
\text { (kg) }\end{array}$} \\
\hline & Laki-Laki & Perempuan \\
\hline Fleksi Siku Kanan & 2,45 & 2,34 \\
\hline Fleksi Siku Kiri & 2,62 & 2,15 \\
\hline Ekstensi Siku Kanan & 2,42 & 2,14 \\
\hline Ekstensi Siku Kiri & 2,55 & 1,98 \\
\hline Fleksi Bahu Kanan & 2,15 & 1,75 \\
\hline Fleksi Bahu Kiri & 2,10 & 1,60 \\
\hline Ekstensi Bahu Kanan & 2,52 & 1,89 \\
\hline Ekstensi Bahu Kiri & 2,50 & 1,73 \\
\hline Abduksi Bahu Kanan & 2,15 & 1,95 \\
\hline Abduksi Bahu Kiri & 1,95 & 1,73 \\
\hline Fleksi Lutut Kanan & 1,77 & 1,67 \\
\hline Fleksi Lutut Kiri & 1,75 & 1,59 \\
\hline $\begin{array}{l}\text { Ekstensi Lutut } \\
\text { Kanan }\end{array}$ & 1,75 & 1,51 \\
\hline Ektensi Lutut Kiri & 1,87 & 1,35 \\
\hline Dorsofleksi Kanan & 1,35 & 1,40 \\
\hline Dorsofleksi Kiri & 1,25 & 1,29 \\
\hline
\end{tabular}

\section{Gambaran Kekuatan Otot berdasarkan kelompok umur}

Tabel 4 menggambarkan rerata kekuatan otot pada responden yang berada pada kelompok umur 60-69 tahun memiliki rerata kekuatan otot yang lebih besar daripada kelompok umur 70-79 tahun, 8089 tahun dan 90 tahun ke atas terutama pada gerakan fleksi siku kanan dan kiri, ekstensi siku kanan, serta abduksi kanan dan kiri. Pada gerakan lainnya rerata kekuatan otot responden yang berada pada kelompok umur 70-79 tahun memiliki kekuatan otot yang lebih besar dari kelompok umur 60-69 tahun, 80-89 tahun dan 90 tahun ke atas.

Tabel 4. Rerata Kekuatan Otot berdasarkan Kelompok Umur

\begin{tabular}{|c|c|c|c|c|}
\hline \multirow[b]{2}{*}{ Gerakan } & \multicolumn{4}{|c|}{ Rerata Kekuatan Otot (kg) } \\
\hline & $60-69$ & $70-79$ & 80-89 & $>90$ \\
\hline $\begin{array}{l}\text { Fleksi Siku } \\
\text { Kanan }\end{array}$ & 2,87 & 2,68 & 1,91 & 1 \\
\hline $\begin{array}{l}\text { Fleksi Siku } \\
\text { Kiri } \\
\text { Fkctonci Sikı1 }\end{array}$ & 2,56 & 2,56 & 2,08 & 1 \\
\hline $\begin{array}{l}\text { Kanstisi siku } \\
\text { Kan }\end{array}$ & 2,62 & 2,5 & 1,91 & 0,75 \\
\hline $\begin{array}{c}\text { Ekstensi Siku } \\
\text { Kiri } \\
\text { Fleksi Bahu }\end{array}$ & 2,25 & 2,5 & 1,94 & 0,75 \\
\hline $\begin{array}{l}\text { Kanan } \\
\text { Fleksi Bahu }\end{array}$ & 2,06 & 2,14 & 1,63 & 0,75 \\
\hline $\begin{array}{c}\text { Kiri } \\
\text { Ekstensi Bahu }\end{array}$ & 1,87 & 2,08 & 1,5 & 0,75 \\
\hline $\begin{array}{c}\text { Kanan } \\
\text { Ekstensi Bahu }\end{array}$ & 2 & 2,5 & 1,86 & 0,75 \\
\hline Kiri & 2 & 2,41 & 1,66 & 0,75 \\
\hline $\begin{array}{l}\text { Abduksi Bahu } \\
\text { Kanan } \\
\text { Abduksi Bahu }\end{array}$ & 2,62 & 2,1 & 1,8 & 0,75 \\
\hline Kiri & 2,18 & 2,04 & 1,47 & 0,75 \\
\hline $\begin{array}{l}\text { Kanan } \\
\text { Fleksi Lutut }\end{array}$ & 1,75 & 1,97 & 1,5 & 0,25 \\
\hline $\begin{array}{c}\text { Kiri } \\
\text { Ekstensi Lutut }\end{array}$ & 1,62 & 2 & 1,36 & 0,25 \\
\hline $\begin{array}{c}\text { Kanan } \\
\text { Ektensi Lutut }\end{array}$ & 1,93 & 1,95 & 1,13 & 0,25 \\
\hline $\begin{array}{c}\text { Kiri } \\
\text { Dorsofleksi }\end{array}$ & 1,93 & 2,02 & 1,16 & 0,25 \\
\hline $\begin{array}{c}\text { Kanan } \\
\text { Dorsofleksi }\end{array}$ & 1,56 & 1,66 & 1,05 & 0,25 \\
\hline Kiri & 1,37 & 1,58 & 0,9 & 0,25 \\
\hline
\end{tabular}




\section{BAHASAN}

\section{Karakteristik Responden}

Jumlah responden pada penelitian ini yaitu 26 orang lansia yang tinggal di Balai Penyantunan Lanjut Usia Senja Cerah. Pada tabel 1 diketahui bahwa jumlah responden berjenis kelamin perempuan lebih banyak yaitu 16 orang (61,5\%), sedangkan laki-laki 10 orang (38,5\%). Hal ini disebabkan karena jumlah lansia yang tinggal di panti tersebut lebih banyak perempuan dibandingkan dengan laki-laki. Rerata umur dari responden yaitu 75,85 \pm 7,61 tahun, dengan umur terbanyak 72 tahun. Umur minimal responden yaitu 60 tahun dan umur maksimal 93 tahun.

\section{Gambaran Kekuatan Otot berdasarkan Jenis Kelamin}

Pada tabel 3 yang menggambarkan kekuatan otot berdasarkan jenis kelamin diketahui bahwa rerata kekuatan otot lakilaki pada setiap gerakan yang dilakukan lebih besar daripada kekuatan otot perempuan, yaitu pada gerakan fleksi siku kanan dan kiri (2,45 kg dan 2,62 kg) , ekstensi siku kanan dan kiri (2,42 kg dan 2,55 kg), fleksi bahu kanan dan kiri (2,15 kg dan 2,10 kg), ekstensi bahu kanan dan kiri (2,52 kg dan 2,5 kg), abduksi bahu kanan dan kiri (2,15 kg dan 1,95 kg) serta fleksi lutut kanan dan kiri (1,77 kg dan 1,75 kg), juga pada ekstensi lutut kanan dan kiri (1,75 kg dan 1,87 kg). Pada gerakan dorsofleksi kanan dan kiri menunjukkan bahwa rerata kekuatan otot perempuan (1,40 kg dan 1,29 kg) lebih besar daripada rerata kekuatan otot laki-laki (1,35 kg dan $1,25 \mathrm{~kg})$.

Pada umumnya laki-laki lebih kuat dibandingkan dengan perempuan. Hal itu disebabkan oleh adanya perbedaan massa otot. Peningkatan kekuatan ini berkaitan dengan peningkatan massa otot setelah puber, karena setelah masa puber massa otot pria $50 \%$ lebih besar dibandingkan dengan massa otot wanita. ${ }^{7}$ Penelitian sejenis yang dilakukan oleh Santoso didapatkan rerata nilai $1 \mathrm{RM}$ pada laki-laki yaitu $17,13 \mathrm{~kg}$ sedangkan rerata nilai $1 \mathrm{RM}$ pada perempuan yaitu 13,62 kg. Dengan begitu, nilai $1 \mathrm{RM}$ otot kuadriseps femoris menurut jenis kelamin menunjukkan nilai 1 RM pada laki-laki lebih besar daripada perempuan. ${ }^{8}$ Begitu juga dengan penelitian yang dilakukan oleh Putrawan dan Kuswardhani didapatkan rerata kekuatan genggaman tangan pada laki-laki lebih tinggi daripada perempuan. ${ }^{9}$ Chen dalam penelitiannya mendapatkan bahwa kekuatan otot pada perempuan lebih rendah dari kekuatan otot laki-laki. Perempuan memiliki kekuatan otot $37-68 \%$ dari kekuatan otot laki-laki. Perbedaan kekuatan otot antara laki-laki dan perempuan lebih menonjol pada ke kuatan anggota tubuh bagian atas daripada anggota tubuh bagian bawah. Perempuan cenderung memiliki kekuatan otot yang lebih besar pada kaki daripada tangan dan bahu. ${ }^{10}$

\section{Gambaran Kekuatan Otot berdasarkan Kelompok Umur}

Pada tabel 4 yang menggambarkan kekuatan otot berdasarkan kelompok umur pada lima gerakan tangan yaitu fleksi siku, ekstensi siku, fleksi bahu, ekstensi bahu, abduksi bahu serta 3 gerakan kaki yaitu fleksi lutut, ekstensi lutut, dan dorsofleksi. Responden yang berada dalam kelompok umur 60-69 tahun memiliki rerata kekuatan otot yang lebih besar dibanding kelompok umur 70-79 tahun, 80-89 tahun dan 90-99 tahun saat fleksi siku, ekstensi siku dan abduksi bahu. Sementara itu, kelompok umur 80-89 tahun dan 90-99 tahun secara konsisten memiliki rerata kekuatan otot yang rendah pada tiap gerakan Hal tersebut menunjukan bahwa seiring bertambahnya usia kekuatan otot semakin menurun. Akan tetapi, pada gerakan fleksi bahu, ekstensi bahu, fleksi lutut, ekstensi lutut dan dorsofleksi responden yang berada dalam kelompok umur 70-79 tahun memiliki rerata kekuatan otot yang sedikit lebih besar dibanding dengan responden yang berada dalam kelompok umur 60-69 tahun. Hal ini disebabkan karena sebagaian besar responden terdistribusi pada mereka yang berumur kisaran 70-79 tahun yang berjumlah 12 orang (46,2\%). Selain itu, pada anamnesa yang dilakukan saat 
penelitian didapatkan bahwa cukup banyak responden yang berada dalam kelompok umur 70-79 tahun yang sebelumnya sering melakukan latihan beban.

Proses penuaan mengakibatkan penurunan kekuatan otot. ${ }^{5-9}$ Menurut GoodPaster, dkk lansia baik laki-laki maupun perempuan mengalami penurunan kekuatan otot. $^{11}$ Menurut penelitian Grosicki kekuatan otot pada usia dewasa muda lebih besar dibandingkan dengan lansia. $^{12}$

\section{SIMPULAN}

Dari hasil penelitian dapat disimpulkan bahwa:

1. Lansia berjenis kelamin laki-laki memiliki rerata kekuatan otot yang lebih besar dibanding perempuan.

2. Lansia dalam kelompok umur 70-79 memiliki kekuatan otot yang lebih besar dibanding kelompok umur yang lain pada gerakan, ekstensi siku kiri, fleksi bahu kanan dan kiri, ekstensi bahu kanan dan kiri, fleksi lutut kanan dan kiri, ektensi lutut kanan dan kiri, serta dorsofleksi telapak kaki kanan dan kiri. Lansia dengan kelompok umur 60-69 tahun memiliki kekuatan otot yang lebih beasr dibanding kelompok umur yang lain pada gerakan fleksi siku kanan dan kiri, ekstensi siku kanan dan abduksi bahu kanan dan kiri.

\section{SARAN}

1. Perlu dilakukan penelitian lebih lanjut dengan responden yang lebih banyak dan waktu yang lebih lama.

2. Perlu dilakukan penelitian terhadap faktor-faktor lain yang dapat mempengaruhi kekuatan otot, misalnya berat badan.

\section{DAFTAR PUSTAKA}

1. World Health Organization. Ageing [Internet]. 2014 [cited 2014 sept 14]. Available from: http://www.who.int/topics/ageing/en/

2. Penduduk Lanjut Usia [Internet]. 2010 [cited
2014 Sept 14]. Available from : http://www.menegpp.go.id/v2/index.php/dat adaniformasi/kependudukan?doownload=9 \%3Apenduduk-lanjut-usia.

3. Nair K. Aging muscle. Am J Clin Nutr. 2005;81:953-63.

4. Lambert C, Evans W. Effects of aging and resistance exercise on determinants of muscle strength. J Am Aging Assoc. Apr 2002; 25(2): 73-8.

5. Andersson D, Betzenhauser M, Reiken S, Meli A, Umanskaya A, Xie W, et al. Ryanodine receptor oxidation causes intracellular calcium leak and muscle weakness in aging. Cell Metabolism. 2011;14:196-207

6. Mayer F, Scharhag-Rosenberger F, Carlsohn A, Cassel M, Müller S, Scharhag J. The intensity and effects of strength training in the elderly. Dtsch Arztebl Int. 2011;108(21):359-64.

7. Lesmana S. Perbedaan pengaruh metode latihan beban terhadap kekuatan dan daya tahan otot biceps brachialis ditinjau dari perbedaan gender. 2012 September 5 [cited 2014 sep 15]. Available from : http://www.esaunggul.ac.id/article/perbedaa n-pengaruh-metode-latihan-beban-terhadapkekuatan-dan-daya-tahan-otot-bicepsbrachialis-ditinjau-dari-perbedaan-genderstudi-komparasi-pemberian-latihan-bebanmetode-delorme-dan-metode-oxford/

8. Santoso SD.Gambaran nilai 1 RM otot kuadriseps femoris pada subyek sehat berumur 18-25 tahun [masters thesis]. Semarang: Universitas Diponegoro; 2005.

9. Putrawan IB, Kuswardhani RA. Faktorfaktor yang menentukan kekuatan genggaman tangan pada pasien lanjut usia di panti wredha tangtu dan polikinik geriatri rsup sanglah. J Peny Dalam. 2011;2:88-9.

10. Chen G, Liu L, Yu J. A comparative study on strength between American college male and female students in caucasian and asian populations. Sports Science Review. 2012;21:153-63.

11. Goodpaster BH, Park SW, Harris TB, Kritchevsky SB, Nevitt M, Schwartz AV, et al. The loss of skeletal muscle strength, mass, and quality in older adults: the health, aging and body composition study. Journal of Gerontology. 2006;61A:1059-64.

12. Grosicki GJ, Miller ME, Marsh AP. Clinical Interventions in Aging 2014:9 209-18. 